\title{
Concrete Asphalt Marshall Stability Using Concrete Objective Waste
}

\author{
Sumargono, Agata Iwan Candra, Ahmad Ridwan, Budi Winarno, Ki Catur Budi, \\ Dwifi Aprilia Kharisma \\ Civil Engineering Department, Kadiri University \\ sumargono@unik-kediri.ac.id
}

\begin{abstract}
The road is one of the most important infrastructures. The community needs it because the road functions to connect the source of production. Asphalt is an aggregate binding material in road pavement construction, which plays an important role in determining road pavement performance. Road Pavement, in general, uses materials that are still fairly common. This study uses a fine aggregate of crushed concrete specimens. The method used is an experiment on the addition of concrete test specimens with percentages of $10 \%, 20 \%, 30 \%, 40 \%$, and $50 \%$. Marshall method which is the basis for calculating the stability value and flow. the results of 5 Marshall test samples of asphalt concrete mix utilizing concrete waste obtained the characteristics of the average value of the study that all had met Highways' requirements at a VMA value of $18.22 \%$, a value of 4.22 VIM. $\%$, VFB value $75.04 \%$, STABILITY value $4806 \mathrm{~kg}$, FLOW value $3.24 \mathrm{~mm}$, and Marshall Quotient (MQ) value $14958.1 \mathrm{~kg} / \mathrm{mm}$.
\end{abstract}

Keywords: Marshall Method, Laston, Concrete Test Wastes

\section{INTRODUCTION}

The road is a land transportation infrastructure, which is a supplementary building for traffic movement.(Hasan et al., 2020) in general, ways are below and above ground and water levels. (Government Regulation No. 34 of 2006 concerning Roads).(Syaifuddin dan Hasilani, 2013) The material to be used must meet the characteristics of flexibility, stability, durability, and water resistance.(Gunarto, 2019) Concrete Asphalt Layer is a cover for road pavement construction with structural value first developed in America by The Asphalt Institute under the name Asphalt Concrete (AC).(Borges Cabrera et al., 2017) According to the Public Works Department of Bina Marga, this mixture consists of continuous gradation aggregates with hard Asphalt, mixed, spread, and compacted in hot conditions at a specific temperature.(Widojoko \& Purnamasari, 2012) The mixing temperature is determined based on the type of Asphalt to be used.(Ziari et al., 2019) Whereas what is meant by continuous gradation is a composition that shows an even distribution of grains ranging from the most significant size to the smallest size.(Dalhat et al., 2020) Asphalt concrete with continuous gradation mixture has a composition consisting of coarse Aggregate, Fine Aggregate, mineral filler (filler), and Asphalt (bitumen) as a binder.(Zhou et al., 2019) In general, the use of asphalt pavement composition is $4-10 \%$ based on the mixture's total weight. Natural Aggregate is one of the main elements of asphalt mixture, base lane, and subbase of highways, airports, walkways, and parking lots.(Nwakaire et al., 2020) It is also an equally important material for Portland cement concrete mixtures used in rigid pavement construction, buildings, industrial facilities, and land structures.(Arabani \& Mirabdolazimi, 2011)

Aggregates and their fractions processed thus become essential industrial commodities for the construction sector. Natural aggregates are the main ingredient in a mixture of asphalt 
concrete and cement Portland.(Gunarto \& Candra, 2019) Concrete waste of test specimens derived from sample specs can be used in asphalt mixtures to eliminate potential problems arising from disposing of materials and saving natural aggregate resources.(Fanani et al., 2017) This study uses a revised standard Marshall design method to prepare specimens that meet the minimum size and aspect ratio requirements in uniaxial testing.(Utama, 2005) The use of recycled concrete aggregates in highway construction, i.e., as an aggregate of asphalt mixture or Portland cement mixture, is one way to reduce the need for natural Aggregate because of its considerable economic and environmental benefits.(Firdaus, 2010) Uniaxial testing of laboratory specimens is useful as a measure of the relevant mechanical properties of materials as specific geometric requirements.(Manjunath et al., 2014)

\section{LITERATURE REVIEW}

\subsection{Asphalt}

Asphalt or bitumen is a brown-black material that is viscoelastic. It will soften and melt if it gets enough heating and vice versa.(Lv et al., 2018) Mixing temperature is determined based on the type of Asphalt to be used. If asphalt concrete, the mixing temperature is generally between $145^{\circ} \mathrm{C}$ and $155^{\circ} \mathrm{C}$, so hot Asphalt is called a concrete mixture.(Ahmedzade et al., 2007) This mixture is better known as a hot-mix.(Alenezi et al., 2018) The dominant properties of asphalt concrete are more desirable and will determine the type of asphalt concrete chosen.(Gupta \& Bellary, 2018) It is vital when designing the sidewall thickness. Road classifications that serve light traffic must give preference to Asphalt concrete types with high durability and flexibility(Javilla et al., 2017). The initial optimum estimation of asphalt content estimates the optimal asphalt content, according to the data specifications of the trial results and errors and based on the mixing value.(Anwar, 2016)

\subsection{Aggregate}

Aggregate is the main component of a road pavement structure that is $90-95 \%$ aggregate based on the percentage of weight, or $75-85 \%$ aggregate based on volume.(Jitsangiam et al., 2013) Thus, the quality of the pavement specified by the aggregate properties and the aggregate yield of other ingredients. A total is a collective collection of mineral materials such as sand, gravel, and broken rock.

\subsection{Rough Aggregate}

The coarse aggregate fraction for the design is the Aggregate held by filter No. 8 ( 2.36 $\mathrm{mm}$ ). It must be clean, hard, durable, and free of clays or other undesirable material.(Liu et al., 2018)

Table 1. Rough Aggregate Provisions for Asphalt Concrete Mixture

\begin{tabular}{|l|c|c|}
\hline \multicolumn{1}{|c|}{ Checking type } & Standard & $\begin{array}{c}\text { Conditions } \\
\max / \mathbf{m i n}\end{array}$ \\
\hline Abrasion with Los Angeles machines & SNI 03-3407-1994 & Maks. 12\% \\
\hline brasion with a Los Angeles machine & SNI 03-2417-1991 & Maks. 40\% \\
\hline ggregate adhesiveness to bitumen & SNI 03-2439-1991 & Min. 95\% \\
\hline
\end{tabular}




\begin{tabular}{|l|c|c|}
\hline Angularity & SNI 03-6887-2002 & $95 / 90\left(^{*}\right)$ \\
\hline Flat and Oblong Particles & SNI T-01-2005 & Maks. 10\% \\
\hline Material escaped sieve No.200 & SNI 03-4142-1996 & Maks. 1\% \\
\hline
\end{tabular}

SOURCES: ROUGH AGGREGATE TESTING

\subsection{Fine Aggregate}

Fine aggregates are aggregates that pass filter no. 8 (2.38 mm). (Candra et al., 2020) Fine aggregates consist of natural sand, artificial sand, slag sand, or a combination of these materials. Fine aggregates must be clean, dry, secure, and free of clays and materials which interfere and consist of granules with sharp angles and a gauze surface.(Loaiza \& Colorado, 2018)

Table 2. Excellent Aggregate Provisions for Asphalt Concrete Mixture

\begin{tabular}{|l|c|c|}
\hline \multicolumn{1}{|c|}{ Checking type } & Standard & $\begin{array}{c}\text { Conditions max } \\
\text { I } \mathbf{m i n}\end{array}$ \\
\hline Sand equivalent value & SNI 03-4428-1997 & Maks. 50\% \\
\hline Material escaped sieve No.200 & SNI 03-4142-1996 & Maks. 8\% \\
\hline Angularity & SNI 03-6877-2002 & Maks. 45\% \\
\hline
\end{tabular}

SOURCES: FINE AGGREGATE TESTING

\subsection{Concrete Waste Test Objects}

waste is a material from the production process that can no longer. While the concrete test object waste is a real sample that is no longer in use.(Gunarto \& Candra, 2019)(Moropoulou et al., 2001) The Concrete debris used in this study came from the Civil Engineering Laboratory of Kadiri University

\subsection{Marshall Testing}

This Marshal test aims to determine the stability and stability of the asphalt mixture following SNI 06-2489-1991. Before being tested, the specimens were put in a water bath at $60 \pm 1^{\circ} \mathrm{C}$ for 30 minutes.(Zhou et al., 2019) Then the samples are removed from the sink and placed in a Marshall testing machine for further testing.(Nwakaire et al., 2020)

\section{METHOD}

In this study, an experimental program finds the vulnerability of Asphalt concrete samples using concrete specimen waste as a fine aggregate using revised Marshall procedures. (Gyan \& Univeristy, 2018) Aspect ratio. Laboratory mixtures are prepared on various gradations and asphalt content to determine the number of punch designs needed for the revised Marshall procedure.(Article \& Donner, 2011) In the second phase, the specimen. After all the results of testing the physical properties of the material and by the specifications, then the planning of making test specimens and testing Marshall. The real experimental method True-Experimental Research in this study with experiments in the Civil Engineering laboratory Kadiri University 


\subsection{Tools used}

The equipment used in this study are as follows:

1. A set of sieves to grade fine aggregates and coarse aggregates.

2. Asphalt/ductility test.

3. Los Angeles Aggregate/machine test tool (abrasion test)

4. Dryers are ovens.

5. Digital Scales

6. Specific gravity test equipment.

7. Marshall press.

8. Machine for printing cylindrical specimens with a diameter of 4 inches (10.16) with 3 inches (7.5).

9. Marshall automatic compactor.

10. Ejector

11. Water bath

\subsection{Material Used}

- Rough aggregates/coral

- Fine aggregate/sand is.

- Filler / PC Cement

- Oil asphalt or bitumen

- Concrete Test Object Waste

\subsection{Research Phase}

The research stages will be conducted from the beginning to the end, as explained as follows:

1. Preparation.

For preparing the material, check the tools to be used-preparation of Materials such as Asphalt, Coarse Aggregate, Fine Aggregate, filler.

2. Material testing

- Coarse Aggregate, Fine Aggregate, and filler

Aggregate testing is needed as a filler in asphalt mixtures with gradation compositions following gradations used that meet existing specifications. Coarse and fine aggregates must filter analysis tested, specific gravity, absorption, and filler. The material used is limestone ash, with a level of use of $4 \%$ on each test object. The following are the standard provisions for aggregate inspection.

- Asphalt.

Asphalt testing by conducting penetration tests, softening points, Ductility, specific gravity, and weight loss 


\section{RESULTS AND DISCUSSION}

\subsection{Marshall's Electrical Test Results.}

In this Marshall test there is a mixture of the addition of concrete specimen's waste as a fine aggregate with a percentage of $10 \%, 20 \%, 30 \%, 40 \%, 50 \%$, the results of the Marshall test can be seen in Table 4.

Table 4. Results of Marshall Characteristics Test for All Parameters Taken Average

\begin{tabular}{|c|c|c|c|c|c|c|c|}
\hline No & $\begin{array}{c}\text { Objects } \\
\text { Concrete }\end{array}$ & $\begin{array}{c}\text { VMA } \\
\%\end{array}$ & $\begin{array}{c}\text { VIM } \\
\%\end{array}$ & $\begin{array}{c}\text { VFB } \\
\%\end{array}$ & $\begin{array}{c}\text { Stability } \\
\text { Kg }\end{array}$ & $\begin{array}{c}\text { Flow } \\
\mathbf{m m}\end{array}$ & $\begin{array}{c}\mathbf{M Q} \\
\mathbf{K g} / \mathbf{m m}\end{array}$ \\
\hline 1 & $10 \%$ & 17,79 & 3,21 & 71,49 & 3847 & 3,16 & 1208,4 \\
\hline 2 & $20 \%$ & 18,12 & 4,52 & 74,22 & 4262 & 3,23 & 1387,3 \\
\hline 3 & $30 \%$ & 18,37 & 5,27 & 76,72 & 4956 & 3,25 & 1390,5 \\
\hline 4 & $40 \%$ & 18,39 & 4,78 & 75,81 & 5438 & 3,29 & 1632,4 \\
\hline 5 & $50 \%$ & 18,47 & 3,36 & 76,78 & 5553 & 3,30 & 1672,1 \\
\hline Average & 18,22 & 4,22 & 75,04 & 4806 & 3,24 & 14958,1 \\
\hline \multicolumn{2}{|l|}{ Specification } & $>15 \%$ & $3-5 \%$ & $>65 \%$ & $>800 \mathrm{~kg}$ & $2-4 \mathrm{~mm}$ & $\mathrm{~min} 250$ \\
\hline
\end{tabular}

SOURCES: MARSHALL TESTING RESULTS

From the results of testing the characteristics of the table the highest VMA value is found in the percentage of concrete waste mixture $50 \%$ with a value of $18.47 \%$ and the lowest value in the percentage of concrete specimens waste mixture $30 \%$ with a value of $17.79 \%$, for the highest VIM value is in the percentage of concrete specimens waste mixture $30 \%$ with a value of $5.27 \%$ and the lowest value is in the percentage of concrete specimens waste mixture $10 \% \%$ with a value of $3.21 \%$, for the highest VFB value, it is found in the percentage of the mixture of the concrete specimen waste $50 \%$ with a value of $79.78 \%$, and the value is in the percentage of the concrete specimen mixture $10 \%$ with a value of $71.49 \%$, for the highest stability value is found in the percentage of concrete test object waste mixture $50 \%$ with a stability value of $5555 \mathrm{~kg}$, and for the lowest value stability is in the percentage of concrete mixture test object waste $10 \%$ with a value of $3847 \mathrm{~kg}$, for the highest flow value is the percentage of the mixture of concrete specimens waste $50 \%$ with a value of 3.24 and the lowest value is found in the percentage of the concrete specimens waste mixture $10 \%$, with a value of $3.16 \mathrm{~mm}$, for the highest $M Q$ value contained in the percentage of concrete specimens waste mixture $50 \%$ with the value of $1672.1 \mathrm{~kg} / \mathrm{mm}$ and the lowest value was found in the percentage of the mixture of the waste of the concrete specimen $10 \%$ with a value of $1208.4 \mathrm{~kg} / \mathrm{mm}$.

\subsection{Concrete Mixture at VMA Value}

Based on the 2010 general specifications, Revision 3, Division 6 on Asphalt Pavement requires the highest VMA value in the percentage of demolished concrete specimens $50 \%$ with a value of $18.47 \%$ greater compared with more VMA values in the $10 \%$ concrete specimen waste 
packaging of $17.79 \%$. While the mixture of $20 \%, 30 \%$, and $40 \%$ of each VMA value is $18.12 \%$, $18.37 \%$, and $18.39 \%$.

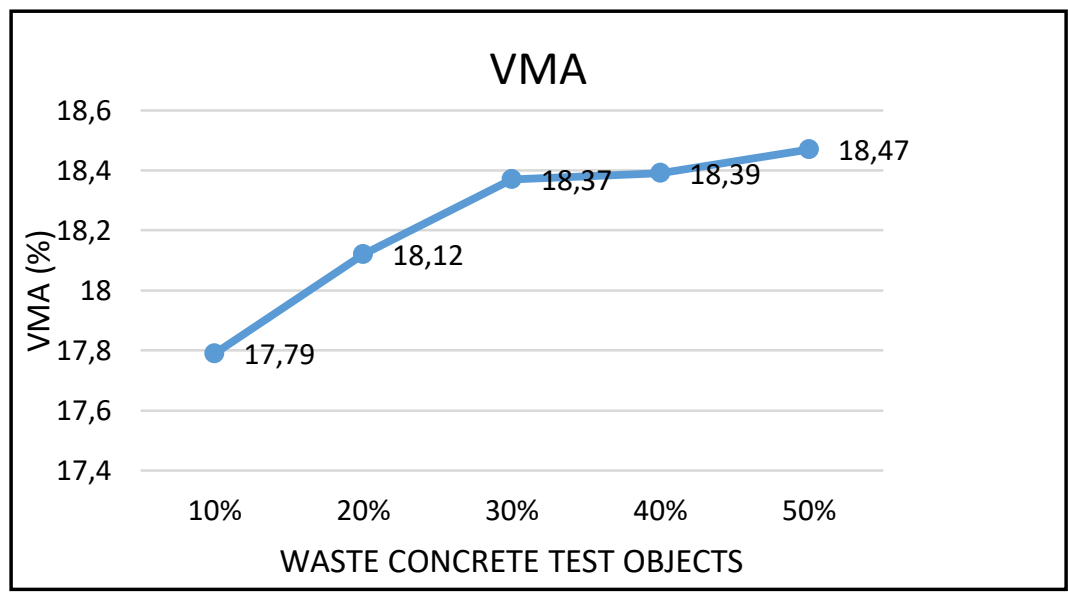

FIGURE 4.2. VMA VALUE GRAPH

\subsection{Concrete Mixture at VIM Value}

Based on the 2010 Bina Marga general specifications, Revision 3, Division 6 on Asphalt Pavement requires that the VIM value in the Asphalt concrete mix specimen waste $30 \%$, must be higher than $5.27 \%$ of the VIM value of percentage $10 \%$ of waste valued at $3.21 \%$. Whereas the mixture of $20 \%, 40 \%$, and $50 \%$ of each VIM value was $4.52 \%, 4.78 \%$, and $3.36 \%$.

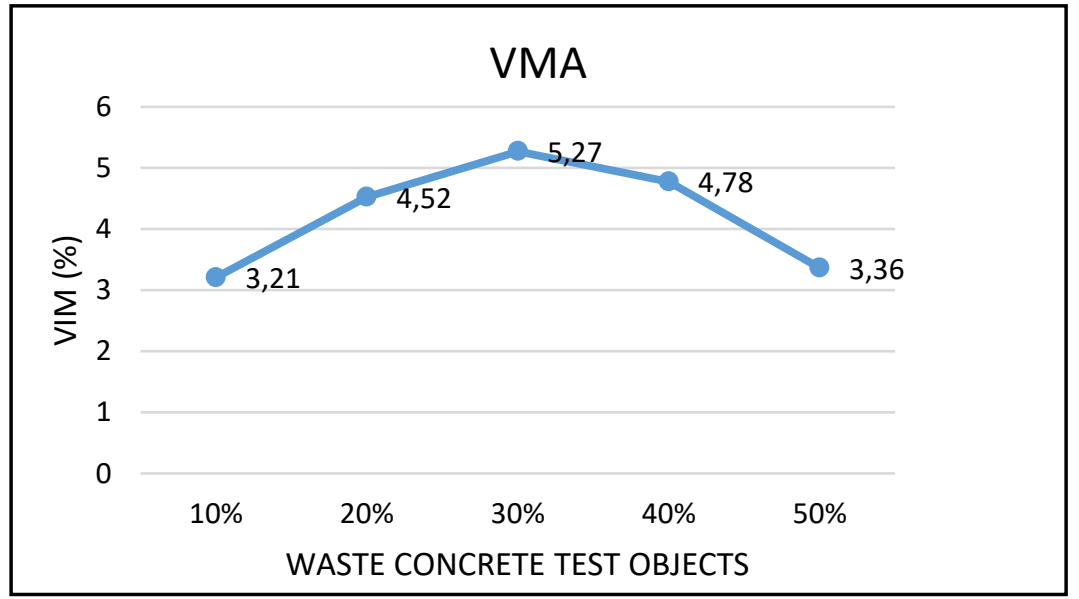

FIGURE 4.3. VIM VALUE GRAPH

\subsection{Concrete Mixture at VFB Value}

Based on the 2010 General Specifications, Revision 3, Division 6 on Asphalt Pavement. The volumetric test results of asphalt mixture using a mixture of concrete specimens as fine Aggregate as a binder in the form of VFB parameters showed values of $71.49 \%, 74.22 \%, 76.72 \%, 75.81 \%$, $76.78 \%$, for each - each has a mixed percentage of $10 \%, 20 \%, 30 \%, 40 \%$, and $50 \%$ and all the mixtures meet the 2010 general specifications, revision 3, division 6 regarding Asphalt Pavement 


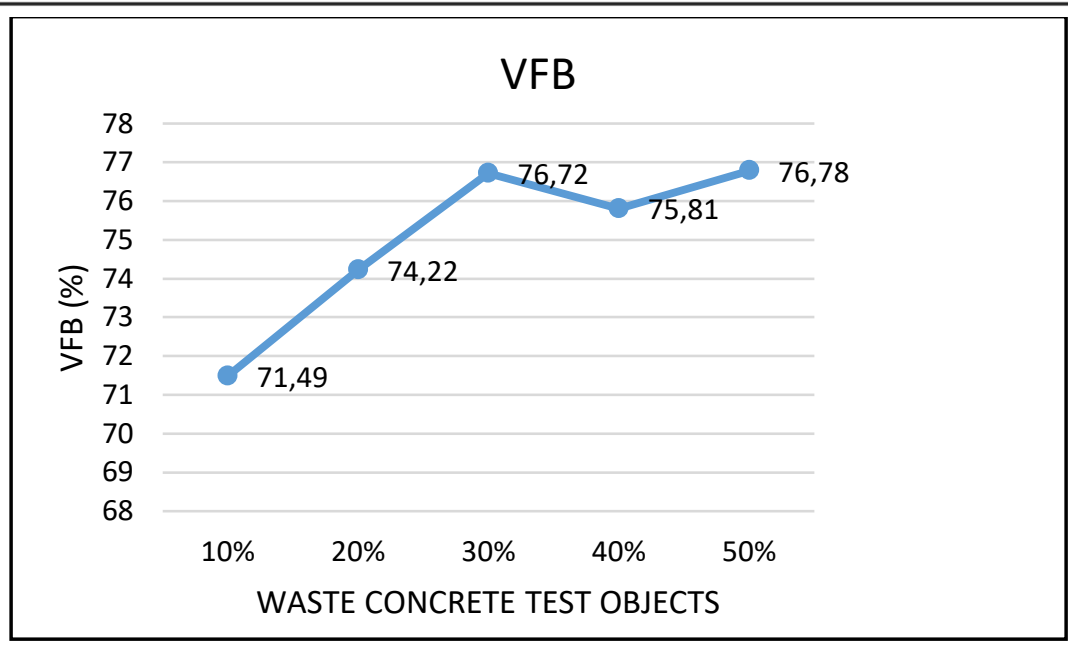

FIGURE 4.4. VFB VALUE GRAPH

\subsection{Concrete Mixture At STABILITY}

The test results' stability value almost meets the specifications of Bina Marga, Revision 3 , 2010.The highest stability value in the mixture of $50 \%$ Concrete Waste is $5,553 \mathrm{~kg}$. The lowest stability value is in $10 \%$ of concrete specimen waste with a stability value of $3847 \mathrm{~kg}$. And all levels of the mixture meet the 2010 general specifications, revision 3, division 6 on Asphalt Pavement

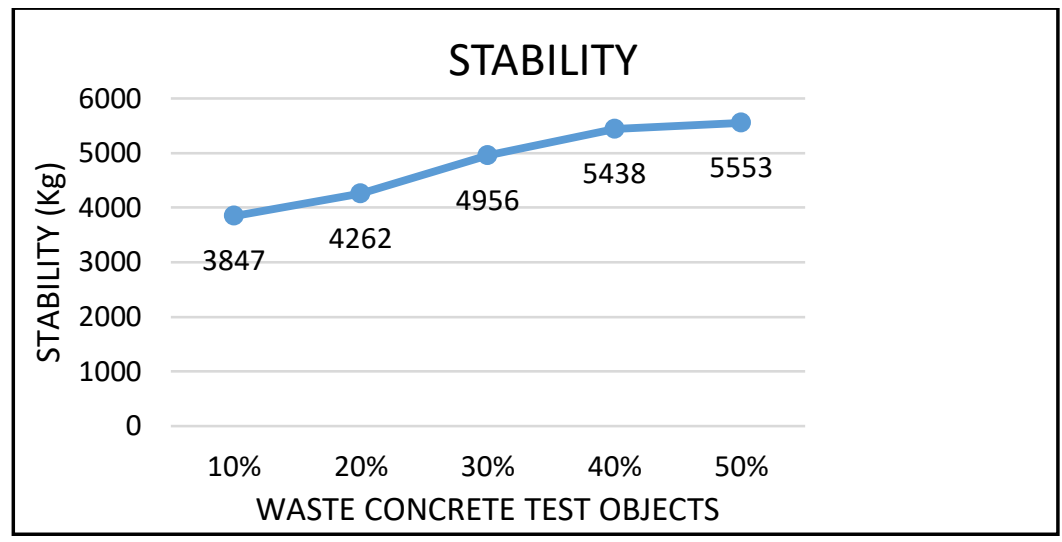

FIGURE 4.5. STABILITY VALUE GRAPH

\subsection{Concrete Mixture at FLOW Value}

Based on the flow values obtained already meet the specifications set by Bina Marga, which is $2 \mathrm{~mm}$ to $4 \mathrm{~mm}$. The flow value in the concrete mixture waste mixture is $10 \%, 20 \%, 30 \%, 40 \%$, and the highest flow value in the $50 \%$ tile mix is $3.30 \mathrm{~mm}$. In comparison, the lowest flow value in the mixture of the test object waste $10 \%$ concrete, with a value of $3.16 \mathrm{~mm}$. 


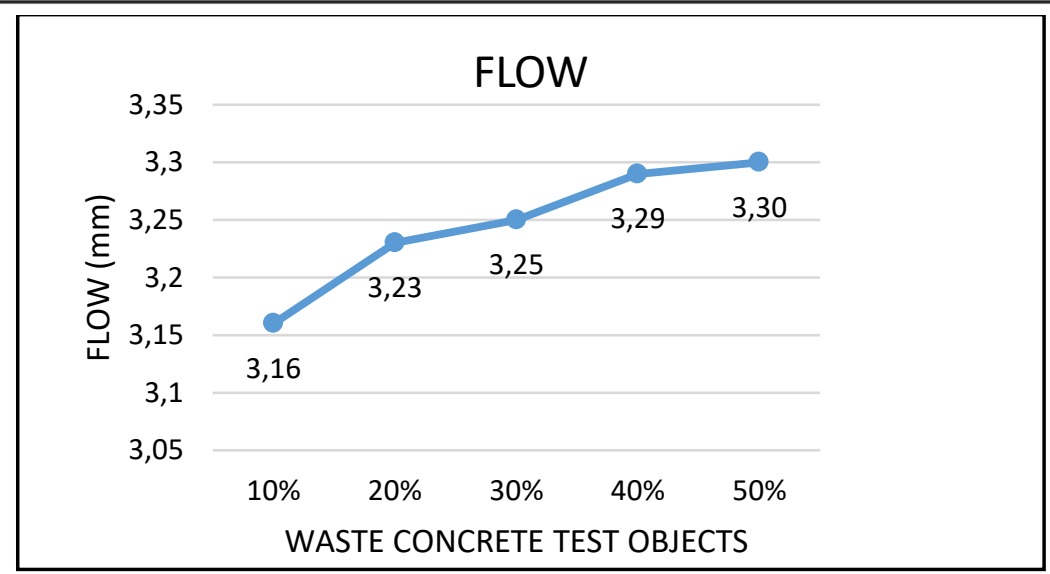

FIGURE 4.6. FLOW VALUE GRAPH

\subsection{Concrete Mixture at MQ Value}

Based on the $M Q$ test results, the lowest $M Q$ value is in the mixture of concrete specimens at a $10 \%$ percentage of $1208.4 \mathrm{~kg} / \mathrm{mm}$. The highest $\mathrm{MQ}$ value in the mixture of concrete specimens with $50 \%$ percentage of $1672.1 \mathrm{~kg} / \mathrm{mm}$, and the respective percentages of $20 \%, 30 \%$, and $40 \%$ are $1387.3 \mathrm{~kg} / \mathrm{mm}, 1390.5 \mathrm{~kg} / \mathrm{mm}$, and $1632.4 \mathrm{~kg} / \mathrm{mm}$. The low MQ value in the percentage of $10 \%$ of concrete specimens waste.

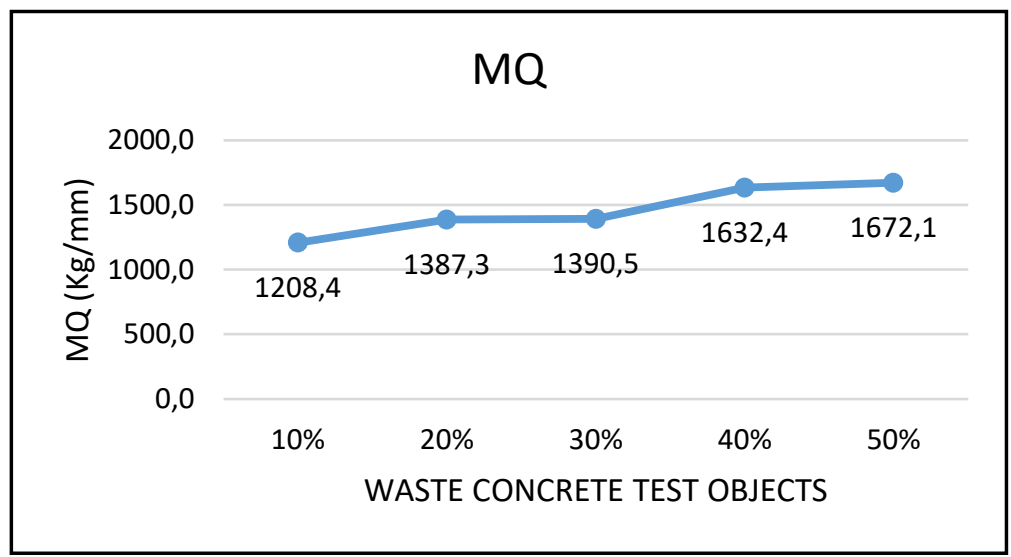

FIGURE 4.7. MQ VALUE GRAPH

\section{CONCLUSIONS}

the use of five samples of concrete waste with an average rating below $10 \%, 20 \%, 30 \%$, $40 \%, 50 \%$ by Marshall method shows VIM, VMA, VFB, Stability Value, Flow, and MQ meet the requirements of Bina Marga:

1. Average VIM value: $4.22 \%$

2. Average VMA value: $18.22 \%$

3. Average VFB value: $75.04 \%$

4. Average Stability Value: $4806 \mathrm{~kg}$

5. Average Flow Value: $3.24 \mathrm{~mm}$

6. Average $M Q$ value: $14958.1 \mathrm{~kg} / \mathrm{mm}$ 


\section{REFERENCES}

Ahmedzade, P., Tigdemir, M., \& Kalyoncuoglu, S. F. (2007). Laboratory investigation of the properties of asphalt concrete mixtures modified with TOP-SBS. Construction and Building Materials, 21(3), 626633. https://doi.org/10.1016/j.conbuildmat.2005.12.003

Alenezi, T., Dawson, A., Garcia, A., \& Dawson, A. (2018). Amount of words with Figures and Tables are: 5832. https://doi.org/10.1016/j.jclepro.2018.11.297

Anwar, S. K. W. (2016). Experimental investigations on Marshall and Modified Marshall specimens by using Neat bitumen. International Journal of Civil Engineering and Technology, 7(5), 409-419.

Arabani, M., \& Mirabdolazimi, S. M. (2011). Experimental investigation of the fatigue behaviour of asphalt concrete mixtures containing waste iron powder. Materials Science and Engineering A, 528(10-11), 3866-3870. https://doi.org/10.1016/j.msea.2011.01.099

Article, R., \& Donner, R. V. (2011). Urban road networks - spatial networks with universal geometric features? A case study on Germany ' $s$ largest cities. 577, 563-564. https://doi.org/10.1140/epjb/e2011-10889-3

Borges Cabrera, M., Satomi, T., \& Takahashi, H. (2017). Study on recycling of waste asphalt blocks containing roadbed materials using new screenless separation equipment with a vibration device. International Journal of Pavement Research and Technology, 10(3), 228-244. https://doi.org/10.1016/j.jprt.2017.01.006

Dalhat, M. A., Osman, S. A., Alhuraish, A. A. A., Almarshad, F. K., Qarwan, S. A., \& Adesina, A. Y. (2020). Chicken Feather fiber modified hot mix asphalt concrete: Rutting performance, durability, mechanical and volumetric properties. Construction and Building Materials, 239, 117849. https://doi.org/10.1016/j.conbuildmat.2019.117849

Fanani, A., Budi, S., Liem, F. N., Alokabel, K., \& Toelle, F. (2017). Terhadap Nilai Stabilitas Pada Campuran Aspal Beton ( Hrs-Wc) Terhadap Karakteristik Uji Marshall. 2(1), 54-63.

Firdaus, Z. (2010). PARAMETER MARSHALL BETON ASPAL AC-WC MENGGUNAKAN MATERIAL DAUR ULANG ( Studi Kasus : Bongkaran Jalan Simpang Dama Kabupaten Aceh Utara).

Gunarto, A. (2019). Penelitian Campuran Aspal Beton Dengan Menggunakan Filler Bunga Pinus. UKaRsT, 3(1), 37. https://doi.org/10.30737/ukarst.v3i1.351

Gunarto, A., \& Candra, A. I. (2019). PENELITIAN CAMPURAN ASPAL BETON DENGAN MENGGUNAKAN FILLER BUNGA PINUS. 3(1), 45-53.

Gupta, L., \& Bellary, A. (2018). ScienceDirect Comparative study on The Behavior of Bituminous Concrete Mix and Warm Mix Asphalt Prepared Using Lime and Zycotherm as Additive. Materials Today: Proceedings, 5(1), 2074-2081. https://doi.org/10.1016/j.matpr.2017.09.203

Gyan, S., \& Univeristy, V. (2018). A Study of Marshall Properties of Bituminous Concrete by using Marshall Hammer at 75 Blows. June.

Hasan, U., Whyte, A., \& Al Jassmi, H. (2020). Life cycle assessment of roadworks in United Arab Emirates: Recycled construction waste, reclaimed asphalt pavement, warm-mix asphalt and blast furnace slag use against traditional approach. Journal of Cleaner Production, 257, 120531. https://doi.org/10.1016/j.jclepro.2020.120531

Javilla, B., Fang, H., Mo, L., Shu, B., \& Wu, S. (2017). Test evaluation of rutting performance indicators of asphalt mixtures. Construction and Building Materials, 155, 1215-1223. https://doi.org/10.1016/j.conbuildmat.2017.07.164

Jitsangiam, P., Chindaprasirt, P., \& Nikraz, H. (2013). An evaluation of the suitability of SUPERPAVE and Marshall asphalt mix designs as they relate to Thailand's climatic conditions. Construction and Building Materials, 40, 961-970. https://doi.org/10.1016/j.conbuildmat.2012.11.011

Liu, P., Xu, H., Wang, D., Wang, C., Schulze, C., \& Oeser, M. (2018). Comparison of mechanical responses of asphalt mixtures manufactured by different compaction methods. Construction and Building Materials, 162, 765-780. https://doi.org/10.1016/j.conbuildmat.2017.12.082

Loaiza, A., \& Colorado, H. A. (2018). Marshall stability and flow tests for asphalt concrete containing electric arc furnace dust waste with high $\mathrm{ZnO}$ contents from the steel making process. Construction and Building Materials, 166, 769-778. https://doi.org/10.1016/j.conbuildmat.2018.02.012

Lv, J., Zhancheng, X., Yingmei, Y., Jiantong, Z., Xiaolong, S., \& Chuanhai, W. (2018). Comparison of Asphalt Mixtures Designed Using the Marshall and Improved GTM Methods. Advances in Materials Science 
and Engineering, 2018. https://doi.org/10.1155/2018/7328791

Manjunath, K. R., N, D. K., \& Thippeswamy, G. S. (2014). Performance and Evaluation on Marshall Stability Properties of Warm Mix Asphalt Using Evotherm and Cecabase Rt ${ }^{\circledR}-A$ Chemical Additive. 12(8), 406-410.

Moropoulou, A., Bakolas, A., \& Aggelakopoulou, E. (2001). The effects of limestone characteristics and calcination temperature to the reactivity of the quicklime. 31.

Nwakaire, C. M., Yap, S. P., Yuen, C. W., Onn, C. C., Koting, S., \& Babalghaith, A. M. (2020). Laboratory study on recycled concrete aggregate based asphalt mixtures for sustainable flexible pavement surfacing. Journal of Cleaner Production, 262, 121462. https://doi.org/10.1016/j.jclepro.2020.121462

Syaifuddin dan Hasilani. (2013). Analisa Parameter Marshall Aspal Beton Ac-Wc Dengan Menggunakan Campuran Retona Blend 55 Dan Aspal Pen 60/70. Jurnal Portal,Issn 2085-7454, VOLUME 5 N(9), 1689-1699. https://doi.org/10.1017/CBO9781107415324.004

Utama, D. (2005). Pengaruh gradasi agregat terhadap kedalaman alur roda pada campuran beton aspal panas. Jurnal Transportasi, 5(1), 87-98.

Widojoko, L., \& Purnamasari, P. E. (2012). Study the Use of Cement and Plastic bottle Waste as Ingredient Added to the Asphaltic Concrete Wearing Course. Procedia - Social and Behavioral Sciences, 43, 832-841. https://doi.org/10.1016/j.sbspro.2012.04.158

Zhou, J., Zeng, M., Chen, Y., \& Zhong, M. (2019). Evaluation of cement stabilized recycled concrete aggregates treated with waste oil and asphalt emulsion. Construction and Building Materials, 199, 143-153. https://doi.org/10.1016/j.conbuildmat.2018.12.028

Ziari, H., Nasiri, E., Amini, A., \& Ferdosian, O. (2019). The effect of EAF dust and waste PVC on moisture sensitivity, rutting resistance, and fatigue performance of asphalt binders and mixtures. Construction and Building Materials, 203, 188-200. https://doi.org/10.1016/j.conbuildmat.2019.01.101

(C) 2020 by the authors. Submitted for possible open access publication under the terms and conditions of the Creative Commons Attribution (CC BY SA) license (https://creativecommons.org/licenses/by-sa/3.0/). 